\title{
Transcriptional suppression of the miR-15/16 family by c-Myc in malignant pleural mesothelioma
}

\author{
Marissa Williams ${ }^{1,2}$, Yuen Yee Cheng ${ }^{1,2}$, Michaela B. Kirschner ${ }^{1,}$, Kadir H. Sarun $^{1}$, \\ Karin Schelch ${ }^{1, \#}$, Patrick Winata ${ }^{1,2}$, Brian McCaughan ${ }^{3}$, Steven Kao ${ }^{1,2,4}$, Nico Van \\ Zandwijk ${ }^{1,2, \dagger}$ and Glen Reid ${ }^{1,2, *}$ \\ ${ }^{1}$ Asbestos Diseases Research Institute, Sydney, Australia \\ ${ }^{2}$ Sydney Medical School, The University of Sydney, Sydney, Australia \\ ${ }^{3}$ RPAH Medical Centre, Sydney, Australia \\ ${ }^{4}$ Chris O’Brien Lifehouse, Sydney, Australia \\ $\S$ Current address: Department of Thoracic Surgery, University Hospital Zurich, Zurich, Switzerland \\ ${ }^{\dagger}$ Current address: Sydney Local Health District, Concord, Australia \\ \#Current address: Institute of Cancer Research, Department of Medicine I, Medical University Vienna, Vienna, Austria \\ *Current address: Department of Pathology, University of Otago, Dunedin, New Zealand \\ Correspondence to: Marissa Williams, email: marissawilliams@live.com.au
}

Yuen Yee Cheng, email: yycheng@adri.org.au

Keywords: mesothelioma; microRNA; C-MYC; transcriptional repression; tumor suppressor

Received: February 12, $2019 \quad$ Accepted: May 04, $2019 \quad$ Published: June 25, 2019

Copyright: Williams et al. This is an open-access article distributed under the terms of the Creative Commons Attribution License 3.0 (CC BY 3.0), which permits unrestricted use, distribution, and reproduction in any medium, provided the original author and source are credited.

\section{ABSTRACT}

MicroRNA downregulation is frequent in malignant pleural mesothelioma (MPM), but the mechanisms responsible for loss of $\mathrm{miR-15/16}$ and $\mathrm{miR-193a}$ are yet to be elucidated and were investigated in this study. Copy Number Variation (CNV) of microRNA-coding genes was analyzed in MPM cells by digital droplet PCR (ddPCR) and revealed heterozygous loss of miR-193a and miR-15a/16-1, but no change in miR15b/16-2. Epigenetic control of microRNA expression was inferred following decitabine and Trichostatin A (TSA) treatment which did not substantially affect microRNA expression. Knockdown of c-Myc expression led to upregulation of SMC4, miR-15b and 16, and to a lesser extent DLEU2 and miR-15a, whereas c-Myc overexpression repressed microRNA expression. Chromatin immunoprecipitation (ChIP) assays confirmed the interaction of C-Myc with the DLEU2 and SMC4 promoters. Tumor microRNA expression was determined in samples from MPM patients, with samples of pleura from cardiac surgery patients used as controls. In tumor samples, a strong correlation was observed between the expression of miR-15b and $16\left(R^{2}=0.793\right)$, but not miR-15a and 16. Our data suggest that in MPM, the downregulation of miR$15 / 16$ is due to transcriptional repression by c-Myc, primarily via control of the miR15b/16-2 locus, while miR-193a-3p loss is due to genomic deletion.

\section{INTRODUCTION}

Malignant pleural mesothelioma (MPM) is a cancer with very poor prognosis and asbestos exposure as the main risk factor, often developing 20-60 years after the date of first asbestos exposure [1]. Median overall survival ranges between 9 and 17 months regardless of stage and the combination of pemetrexed and cisplatin is the current standard of palliative care, offering a modest improvement in patient survival [2]. Attempts to improve disease outcome with targeted therapies were largely 
unsuccessful [3], highlighting the essential requirement for an improved understanding of MPM biology to facilitate the development of effective therapies. Genetic profiling studies in MPM have identified the upregulation of genes involved in cell-cycle, proliferation and chemoresistance $[4,5]$ but effective means of attenuating their expression have not yet been determined. More recently targeting immune checkpoints using antibodies specific for the PD-1/PD-L1 axis have produced promising responses in mesothelioma patients [6]. However, compared to the successes observed in melanoma and lung cancer following immune checkpoint blockade [7], disease control is only observed in a fraction of mesothelioma patients in clinical trials with the majority of patients either relapsing or being refractory to treatment [8]. Poor response may be attributed in part to the low mutational load in MPM, which is considered an important determinant for immune checkpoint inhibition response in melanoma and lung cancer [6].

In addition to the changes in the expression of protein coding genes mentioned above, recent evidence implicates noncoding RNAs (ncRNAs) in many of the phenotypes of MPM cells. MicroRNAs (miRNAs) are an important family of short ncRNAs that posttranscriptionally regulate gene expression through interaction with sites in the $3^{\prime}$ untranslated region (3'UTR) of target messenger RNAs (mRNAs). MiRNAs are initially transcribed as long primary microRNA transcripts (pri-miRNAs) by RNA polymerase II that are capped, polyadenylated $[9,10]$ and subjected to further processing in the nucleus and cytoplasm to generate a mature miRNA [11]. Multiple studies have identified frequent dysregulation of miRNAs in cancer, with many targeting mRNAs involved in tumor progression [12]. The altered expression profiles of miRNAs have assisted in the classification and prognosis of cancer and have been shown to promote tumorigenesis in many malignancies [13] including MPM [14, 15].

As in other malignancies a global downregulation of miRNAs is observed in MPM, with several microRNAs demonstrated to exhibit tumor suppressor activity [16, 17]. MiR-34b/c regulates cell cycle and apoptotic processes via regulation of multiple oncogenic targets including c-Met, CCND1, BCL2, and c-Myc and is downregulated by DNA methylation in approximately $90 \%$ of MPM cases $[14,18]$. In the case of miR-31, loss is via genomic deletion together with the adjacent $C D K N 2 A$ gene and has been associated with tumor recurrence and aggression in MPM patients [19]. In contrast, the underlying mechanisms responsible for the majority of downregulated miRNAs in MPM are largely unknown. This includes for example, the downregulation of $\mathrm{miR}-15 \mathrm{a} / 16-1$ and $\mathrm{miR}-15 \mathrm{~b} / 16-2$ that we recently demonstrated in MPM tumor samples and cell lines. While the anti-tumor functions of miR-15/16 in MPM have been well-characterized in vitro and in vivo [15] and showed promising response in the phase I clinical trial MesomiR-1 [20], the mechanism(s) leading to their downregulation has not been investigated. Similarly, we have also shown that re-expression miR-193a-3p another miRNA consistently downregulated in MPM not only induced apoptosis and reduced cell proliferation of MPM cell lines, but also inhibited MPM xenograft tumor growth to a similar extent as observed with miR16 [15]. Despite the association of the MIR193A gene promoter with $\mathrm{CpG}$ islands and its confirmed silencing by methylation in NSCLC [21] and acute myeloid leukemia (AML) [22], methylation was excluded as a predominant cause of its downregulation in MPM cell lines [23] and the causes for its reduction in MPM remain unknown.

In the current study, we aimed to characterize the mechanisms leading to miRNA downregulation in MPM cell lines by systematically determining whether defects occur at different stages of miRNA biogenesis. Results here provide evidence for the contribution of genomic deletion and transcriptional repression - but not epigenetic regulation - to the suppression of mature miR-15a/16-1, miR-15b/-16-2, and miR-193a-3p levels in MPM cell lines.

\section{RESULTS}

\section{Genomic alterations of miRNA coding genes are observed in MPM}

Copy number variation (CNV) was assessed using digital droplet PCR (ddPCR) in MPM cell lines (Figure 1), revealing heterozygous loss of MIR15A/MIR16-1 in H2052 and H2452 cells (Figure 1A), but no deletion of MIR15B/MIR16-2 (Figure 1B). Levels of mature miR$15 \mathrm{a}$ are consistently low in the MPM cell line panel [15] regardless of MIR15A/MIR16-1 CNV (data not shown), suggesting that gene dosage is not solely responsible for the reduced expression of mature miR-15a or miR-16 from the MIR15A/MIR16-1 locus in MPM. Allelic loss of the MIR193A gene was observed in the majority of MPM cell lines tested (Figure 1C), suggesting that heterozygous deletion of the MIR $193 A$ region is a key contributor to downregulation of miR-193a-3p in MPM.

\section{Epigenetic changes contribute little to downregulation of miR-15/16 and 193a in MPM cell lines}

MiRNA expression was evaluated following treatment with the DNA methylation inhibitor decitabine or the pan-HDAC inhibitor TSA. Decitabine caused a distinct ( 250 -fold) upregulation of miR-34c (Figure $2 \mathrm{~A})$, a miRNA previously shown to be silenced via promoter hypermethylation in MPM [14]. In contrast, negligible changes in expression were observed for miR-15a, miR$15 \mathrm{~b}$ and miR-16 in most cells, however, the expression of 
miR-15/16 is partially affected by decitabine treatment in $\mathrm{H} 2052$ and H2452, suggesting some regulation by DNA methylation in these cell lines (Figure 2A), whereas miR193a-3p expression was only slightly altered. Similarly, TSA treatment did not substantially alter expression of miR-15a, miR-15b, miR-16 or miR-193a-3p (Figure 2B). Collectively, this data suggest that methylation and histone deacetylation are unlikely to be major contributors to the loss of miR-15/16 or miR-193a-3p in MPM cell lines.

\section{Downregulation of pri-miRNA and host gene expression in MPM cell lines}

Both pri-miR-15a/16-1 and pri-miR-15b/16-2 were downregulated in most of the MPM cell lines compared to MeT-5A (Figure 3A). Since pri-miR15a/16-1 and pri-miR-15b/16-2 are transcribed from the promoters of their host genes DLEU2 and SMC4 respectively, we hypothesized that a transcriptional defect

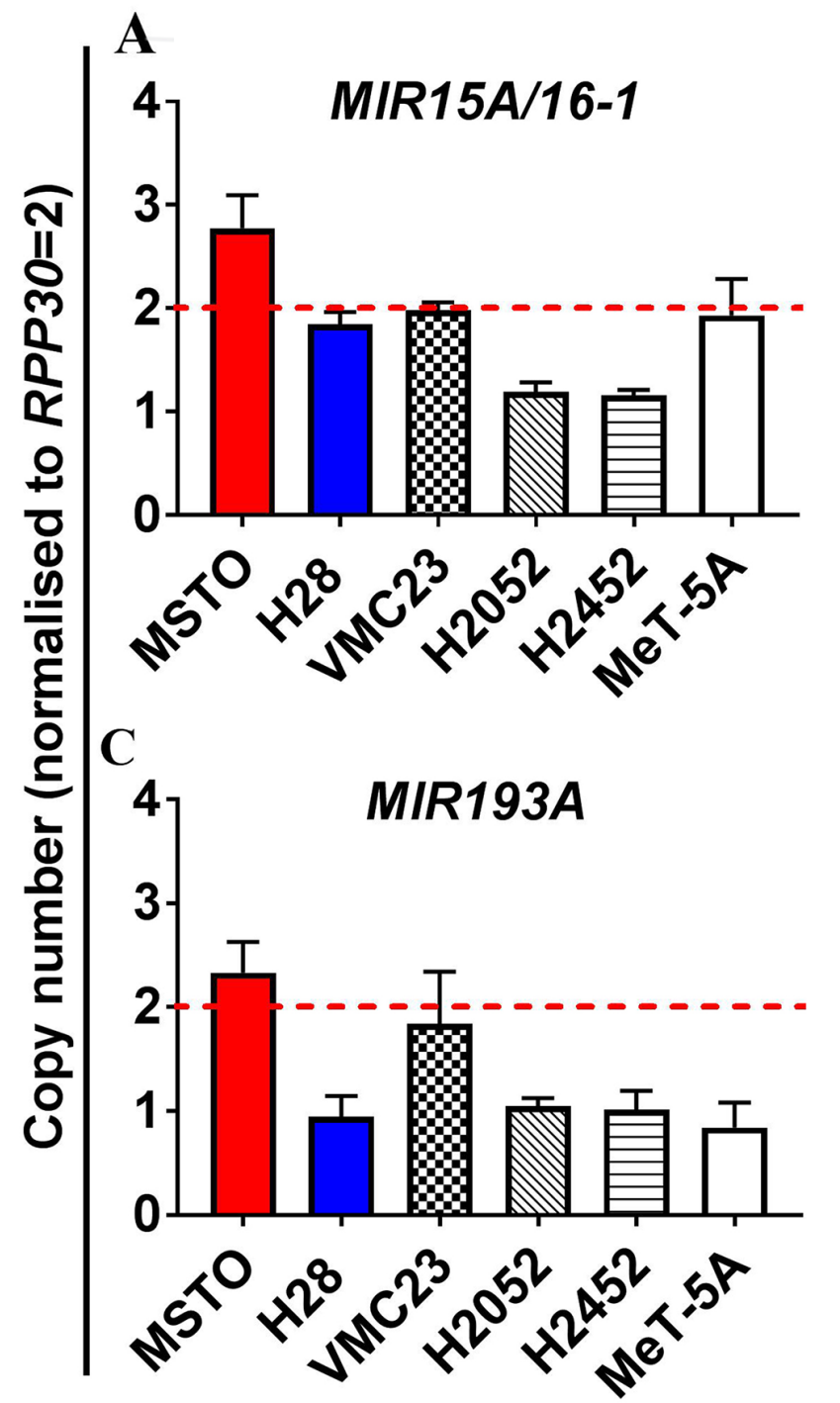

B

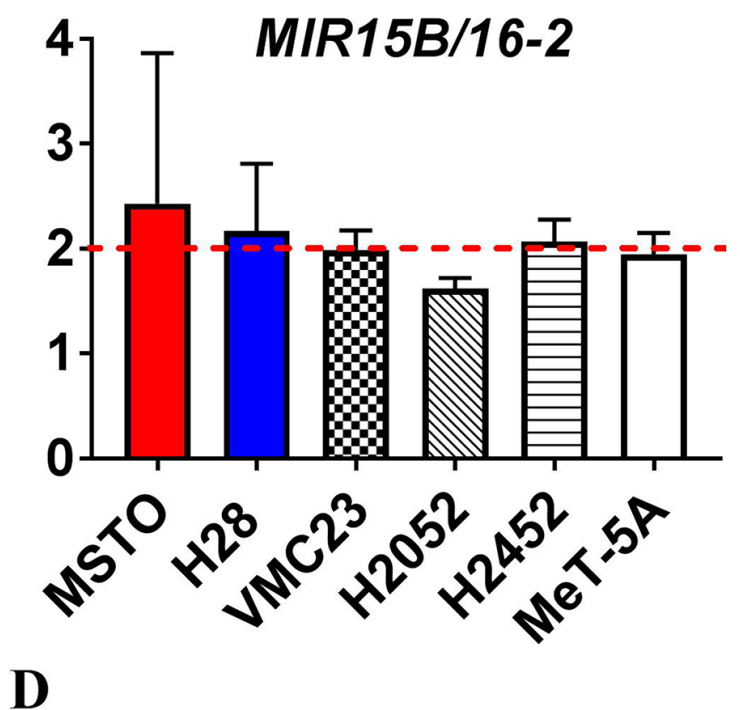

D

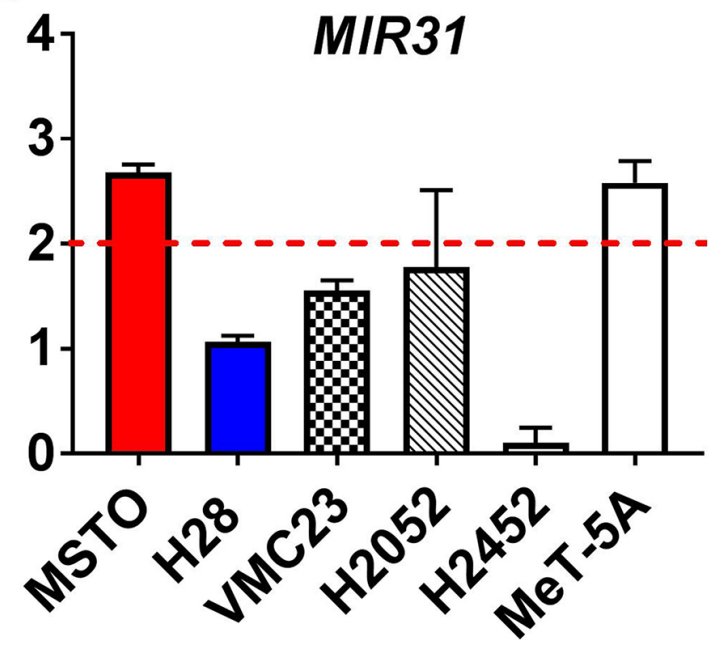

Figure 1: Analysis of copy number variation (CNV) of miRNA genes in MPM reveals allelic loss of the $M I R 193 A$ and to a lesser extent MIR15A/16-1, but not MIR15B/MIR16-2. ddPCR was used to measure the endogenous genomic expression of miRNA coding genes in an MPM cell line panel (MSTO, H28, VMC23, H2052, H2452) as well as the mesothelial cell line MeT-5A. Genomic expression is presented here as copy number determined by normalization to the internal control gene ribonuclease $\mathrm{P}$ protein subunit $\mathrm{p} 30$ (RPP30). Copy number values of $<2$ were considered to indicate heterozygous deletion while a copy number $<1$ demonstrated homozygous loss. (A) No genomic loss of MIR15A/16-1 is determined for MSTO, H28, VMC23 and MeT-5A but heterozygous deletion is observed for H2052 and H2452. (B) No CNV is observed in cell lines for MIR15B/16-2. (C) Heterozygous loss of MIR193A was observed in H28, H2052, H2452 and MeT-5A. (D) MIR31 exhibits heterozygous deletion in H28 and homozygous deletion in H2452. MIR31 loss has previously been identified in H2452 and was included as a positive control for deletion in our cell line panel [19]. All data are the mean of 3 replicate experiments \pm SEM. 
at these loci would affect both pri-miRNA and host gene expression. Similar to the observed reduction in primiRNA expression, the transcription of DLEU2 - and to a greater extent SMC4 - was downregulated in MPM cell lines compared to the mesothelial cell line (Figure 3B), further supporting a transcriptional mechanism of downregulation.

\section{Knockdown of c-Myc upregulates miR-15b/16-2 and inhibits cell growth}

We next investigated the potential role of the oncogenic transcription factor $\mathrm{Myc}$ in miR-15/16 inhibition, as it has been shown to suppress miRNA expression [24-26] and is upregulated in MPM partly due to increased copy number of the $M Y C$ gene [27]. To determine the effects of Myc on miR-15/16 expression in MPM, we knocked down Myc in MSTO and H28 cells, with high and low Myc expression, respectively. Although basal levels of Myc were substantially higher in MSTO cells, expression in both cell lines was reduced significantly upon siRNA transfection (Figure 4A). Myc knockdown led to upregulation of miR-16 levels in MSTO (2-fold) and H28 (1.7-fold) compared to control transfected cells. In addition, Myc downregulation increased miR-15b (4.4 and 2-fold in MSTO and H28, respectively) but had little effect on miR-15a (Figure 4B). As seen in Figure 4C, levels of pri-miR-15b were increased by 10.7-fold and 2.7-fold in MSTO and H28 respectively following transfection with Myc siRNA while co-transcribed SMC4 was elevated by 5.9 -fold in MSTO and 8.1-fold in H28 (Figure 4D). Conversely, levels of pri-miR-15a and DLEU2 showed a more modest increase in expression suggesting that Myc predominantly regulates the miR-15b/16-2 transcript in MPM. As Myc knockdown increased miR-15/16 expression, and these miRNAs inhibit MPM growth in vitro and in vivo [15], we tested the effect of Myc knockdown in MPM cell line growth. Consistent with the effects of Myc on miR-15/16 expression, Myc knockdown significantly reduced proliferation of MSTO cells (Figure 4E).

\section{Overexpression of Myc downregulates miR- 15b/16-2 and miR-15a/16-1 expression}

Given the increase of miR-15b/16-2 and miR15a/16-1 expression following Myc knockdown, we set out to determine the effect of Myc upregulation. Using a MYC expression construct we transiently overexpressed Myc in the low expressing H28 cell line (Figure 5A). Transcription from both the miR-15b/16-2 and miR-15a/16-1 loci were downregulated with Myc overexpression (Figure 5B), consistent with the direct regulation of miR-15/16 by Myc in MPM.

\section{Myc interacts with the promoter regions of DLEU2 and SMC4 in MPM}

Previous studies have demonstrated Myc binding to the promoter region of the DLEU2 gene that hosts the miR-15a/16-1 cluster [24, 28] but to our knowledge, no previous investigation has linked Myc to the transcriptional repression of SMC4, the host gene of the
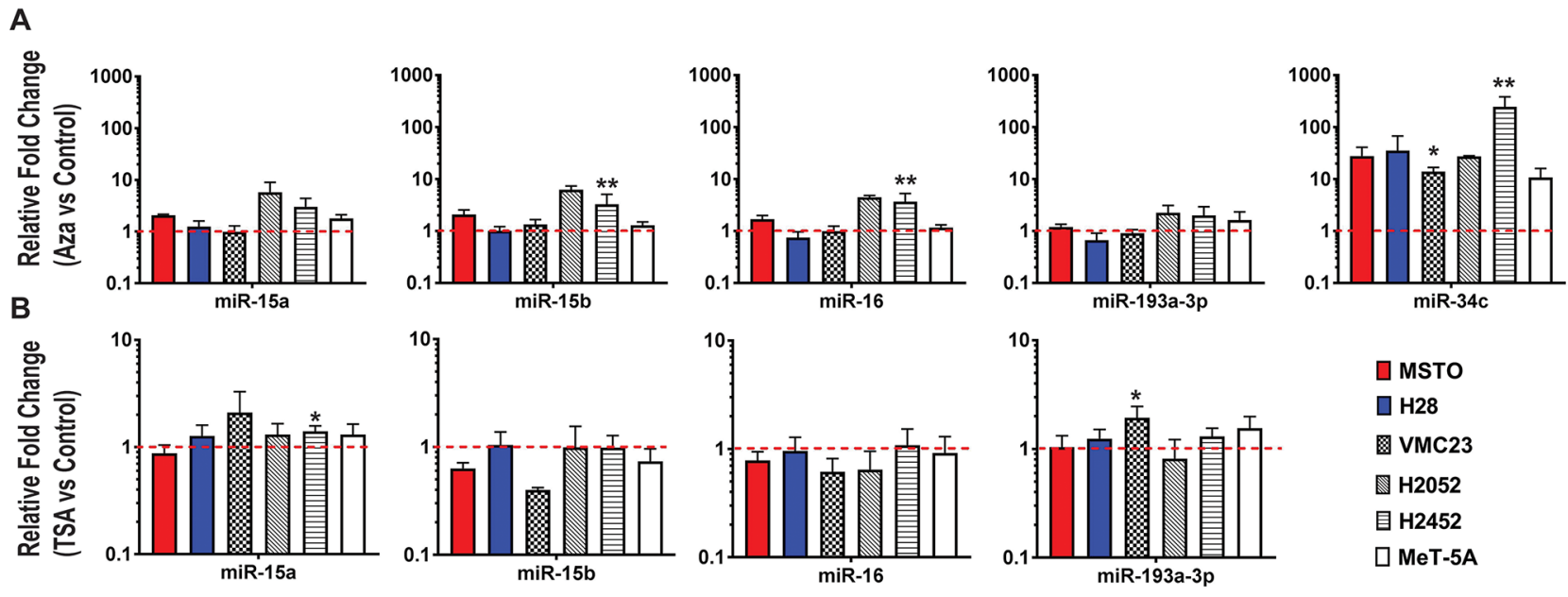

Figure 2: Epigenetic changes do not largely contribute to miR-15/16 downregulation in MPM cell lines. (A) Expression of miR-15a, 15b, 16, 193a-3p and 34c was determined by RT-qPCR after treatment of MPM cell lines with decitabine (Aza). A significant increase in miR-34c expression was evident following treatment but only subtle changes in expression were determined for miR-15a, miR15b, miR-16 and miR-193a-3p. (B) Changes in miRNA expression after $24 \mathrm{~h}$ of treatment with TSA $(1 \mu \mathrm{M})$ was determined in cell lines by RT-qPCR. MiRNA expression in treated cells was compared to cells treated with a vehicle control and normalized to RNU6B. All data are the mean of 3 replicate experiments \pm SEM. ${ }^{*}=\mathrm{p} \leq 0.05 ;^{* *}=\mathrm{p} \leq 0.01$. 
A

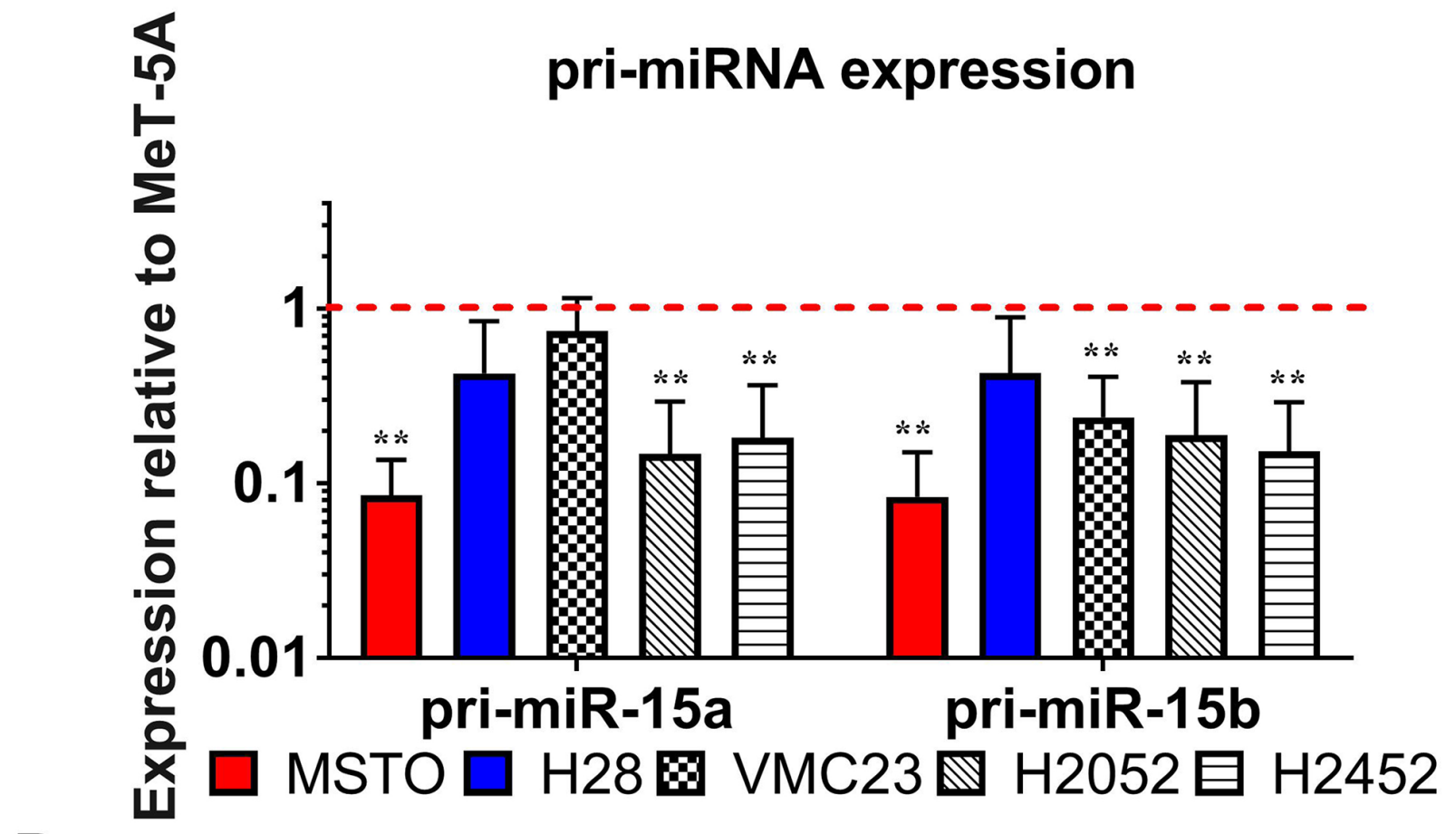

B

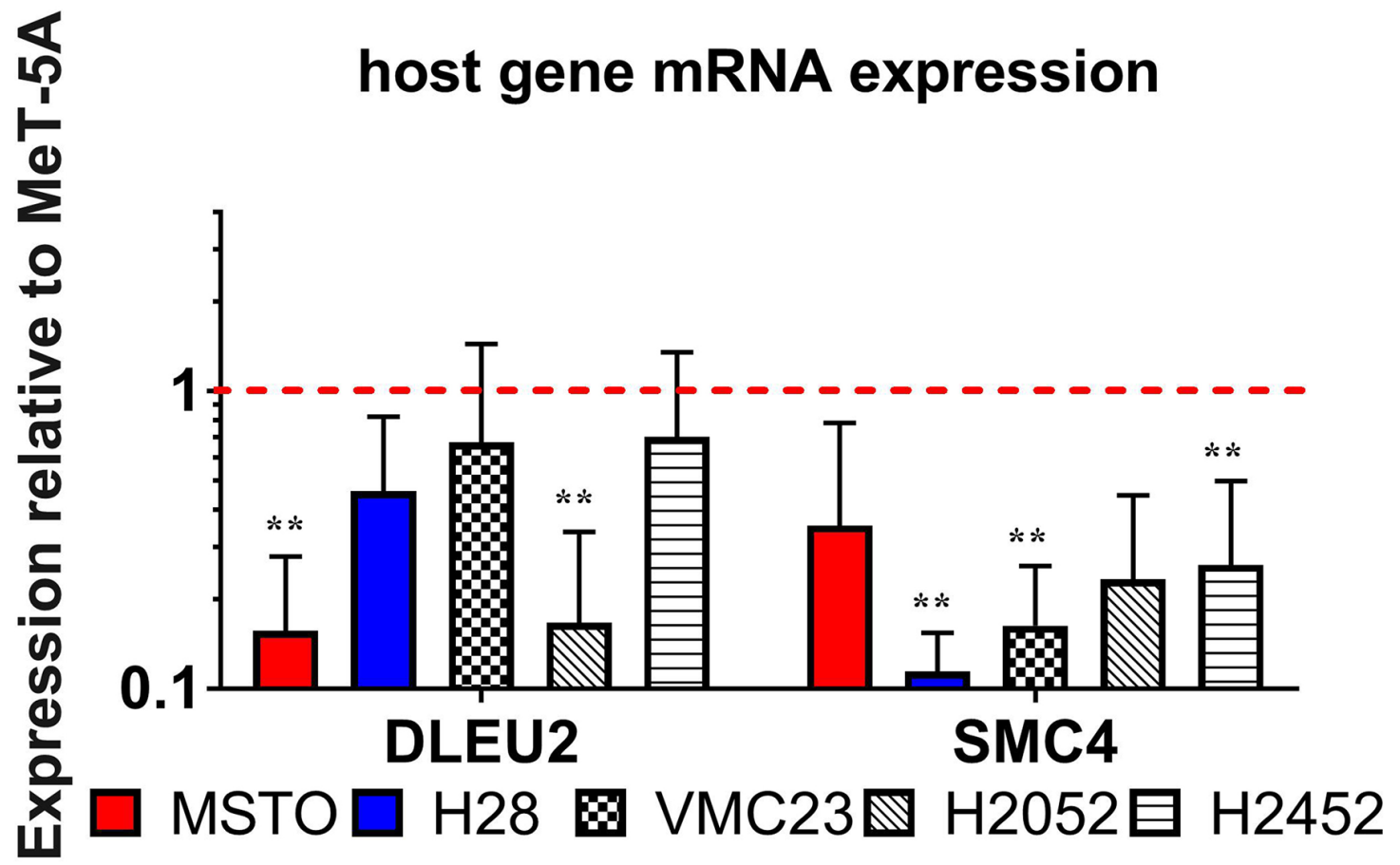

Figure 3: The pattern of expression of miRNA processing intermediates suggest a defect in the transcription of miR-15/16 primary transcripts. RT-qPCR was used to test the endogenous expression of miR-15/16 processing intermediates including host gene mRNA/lncRNA and pri-miRNA expression in the MPM cell line panel. (A) pri-miR-15a and pri-miR-15b also show downregulated expression in all MPM cell lines compared to MeT-5A (red dotted line). (B) host genes DLEU2 and SMC4 are transcribed with miR-15a/16-1 and miR-15b/-16-2 respectively and show downregulated expression in MPM cell lines compared to MeT-5A. Expression values were normalized to $18 \mathrm{~S}$ expression, and are relative to levels in MeT-5A. Results are the mean of 3 biological replicates \pm SEM. ${ }^{* *}=\mathrm{p} \leq 0.01$. 
miR-15b/16-2 cluster. To investigate the role of Myc in controlling transcription of miR-15a/16-1 and miR15b/16-2, we performed chromatin immunoprecipitation (ChIP) experiments and determined enrichment of regions in the DLEU2 and SMC4 promoters (shown schematically in Figure 5C). ChIP-qPCR analysis confirmed the association of the Myc protein with the SMC4 promoter region as seen by 30 -fold enrichment of the SMC4 INR/S amplicons in MSTO and 11-fold in H28
(Figure 5D). Similarly, amplicons S, 1A and 1B designed to span the DLEU2 promoter region produced 50-, 35and 72-fold enrichment respectively following Myc immunoprecipitation. In amplicons $\mathrm{S}$ and $1 \mathrm{~B}$ enrichment was markedly higher in MSTO samples compared to H28 (Figure 5D), probably due to the higher basal Myc expression in MSTO (Figure 4A). Together, these results support a direct interaction between Myc and both the miR-15a/16-1 and miR-15b/16-2 cluster in MPM.

A
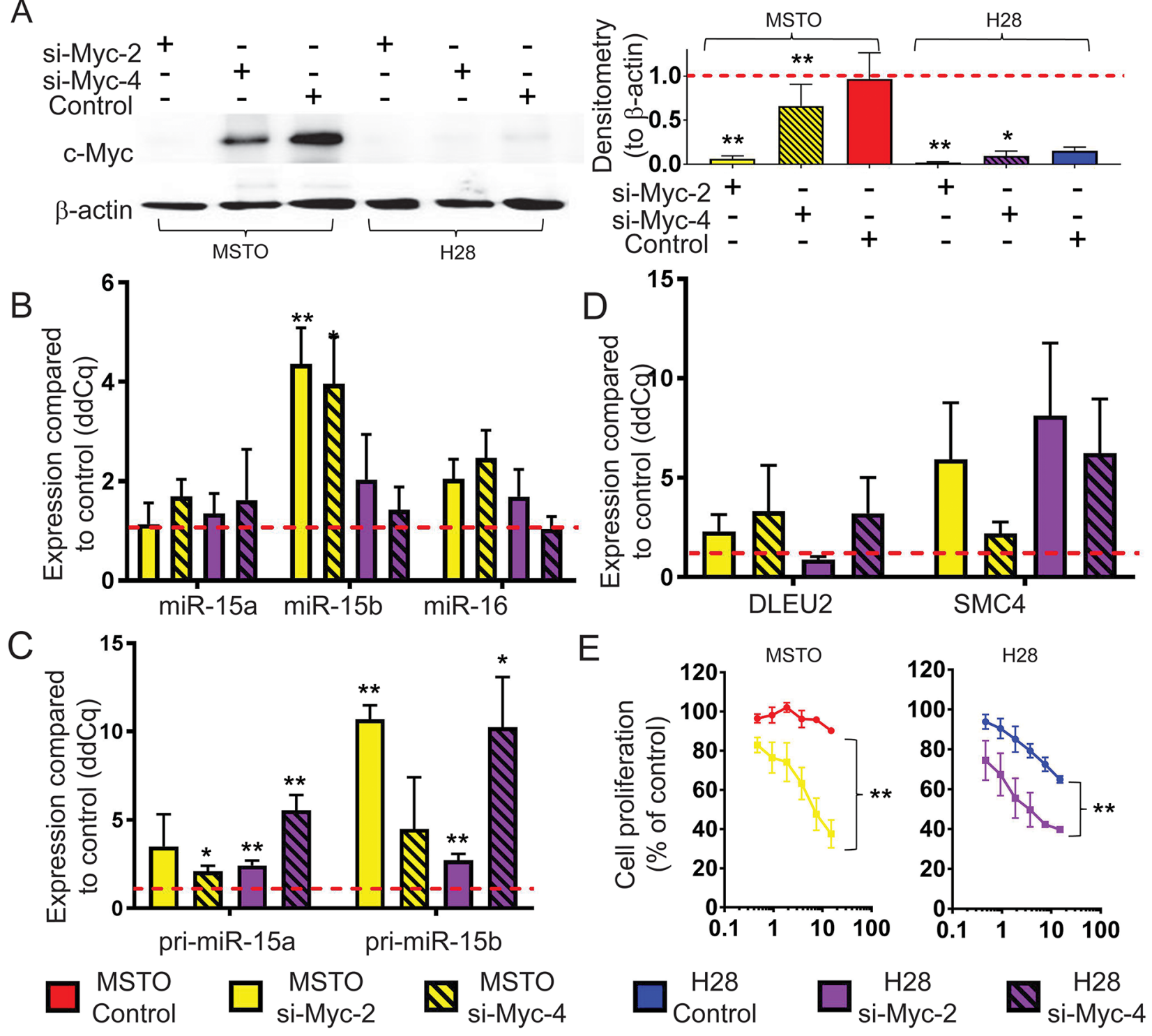

Figure 4: Myc knockdown causes an upregulation of mature miR-15b/16-2 expression and its processing intermediates and inhibits cell growth. (A) Myc protein expression in MPM cell lines with high (MSTO) and low (H28) basal expression $48 \mathrm{~h}$ post transfection with Myc siRNAs (si-Myc-2 and si-Myc-4) and control (all at $20 \mathrm{nM}$ ). $\beta$-actin expression was included as a loading control. Densitometry was used to quantify Myc protein expression from 3 independent experiments that were normalized to $\beta$-actin. Data are mean \pm SD. RT-qPCR was used to measure (B) Mature miRNA, (C) pri-miRNA and (D) host gene mRNA expression levels following transfection with Myc siRNA (si-Myc-2, si-Myc-4) or control transfection. RNU6B was used as a reference gene for miRNA expression while 18s was used as reference for pri-miRNA and host-gene expression. Data is the mean from 3 separate experiments \pm SD. (E) Cell proliferation was measured $96 \mathrm{~h}$ after transfection with si-Myc- 2 or control at the indicated concentrations. Cell proliferation is represented as $\%$ of untransfected cells. Data is expressed as the mean \pm SEM of 3 independent experiments performed in duplicate. ${ }^{*}=\mathrm{p} \leq 0.05 ;{ }^{* *}=\mathrm{p} \leq 0.01$. 


\section{The expression of miR-15b and miR-16 is highly correlated in MPM tumor samples}

Previously we showed that miR-15a, 15b, and 16 were significantly (4 to 22-fold) downregulated in MPM tumors compared with normal pleura [15]. Comparing expression data for each of these miRNAs in individual samples in this data set revealed a strong correlation between miR-15b and $16\left(\mathrm{R}^{2}=0.793\right)$ (Figure 6B), but not between miR-15a and miR-16 (Figure 6A). As a comparison, we analyzed expression of the miR-34 family members in the same samples and found that all were downregulated as shown in Supplementary Figure 1 [miR-34a (1.6-fold, $\mathrm{P}<0.05), 34 \mathrm{~b}$ (1.8-fold, $\mathrm{P}<0.01), 34 \mathrm{c}$

A

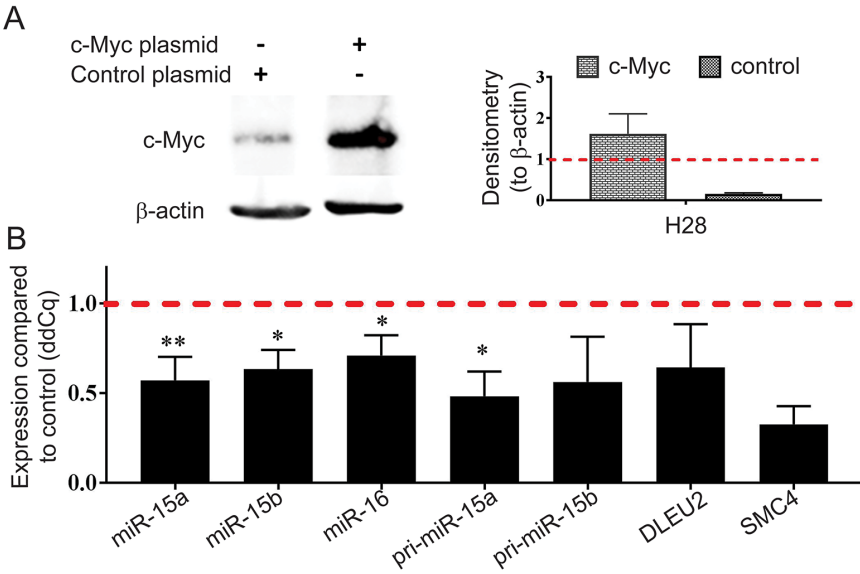

C

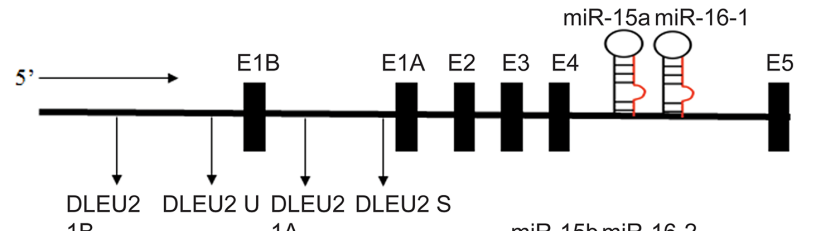

$1 \mathrm{~B}$

$1 \mathrm{~A}$

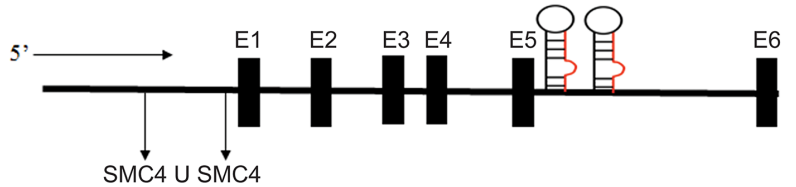

D

SMC4 U SMC4
INR/S

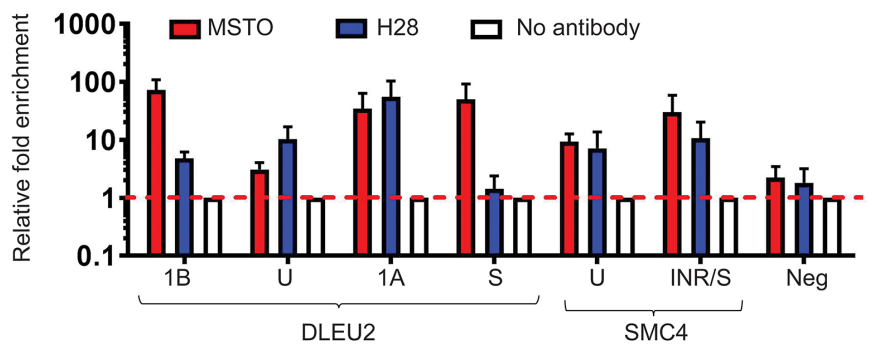

Figure 5: MYC overexpression causes downregulation of miR-15b/16-2 and miR-15a/16-1 and their host genes via binding to the DLEU2 and SMC4 promoters. (A) H28 cells were transfected with pcDNA3.1(+) and pcDNA3.1(+)MYC plasmids and upregulation of Myc protein expression was confirmed via western blotting with $\beta$-actin included as a loading control and normalizer for densitometry. Data are the mean of 3 independent experiments \pm SD. (B) Mature miRNA, pri-miRNA and host gene expression was analyzed using RT-qPCR with RNU6B and 18S as reference genes. MYC construct transfection induced downregulation of mature, priand host gene mRNAs from both the miR-15a/16-1 and miR-15b/16-2 clusters compared to vector control-transfected cells. Data are the mean of 3 independent experiments $\pm \mathrm{SD}$. ${ }^{*}=\mathrm{p} \leq 0.05 ;{ }^{* *}=\mathrm{p} \leq 0.01$. (C) Schematic representation of the promoter regions of the host genes $D L E U 2$ and SMC4 with the amplicon locations used for ChIP analysis indicated below each gene. (D) ChIP was performed using a c-Myc antibody to detect binding to DNA within the DLEU2 and SMC4 promoter regions. DNA enrichment in chromatin immunoprecipitated by the c-Myc antibody was determined by Real-Time PCR. Relative fold-enrichment was then determined by comparing the enrichment with c-Myc antibodies to the enrichment for the no antibody control (Relative enrichment = sample enrichment (Myc)/sample enrichment (no antibody)). A negative control for Myc binding was included that corresponded to a region in chromosome 1 (chr1:204,366,822204,366,872). Data are mean \pm SEM from 3 independent measurements. 
(2.3-fold, $\mathrm{P}<0.0001)]$. For the miR-34 family, expression of the co-transcribed miR-34b and 34c showed substantial correlation $\left(\mathrm{R}^{2}=0.753\right)$ (Figure $\left.6 \mathrm{D}\right)$, whereas miR-34a and $34 \mathrm{~b}$ did not (Figure 6C).

\section{DISCUSSION}

Multiple studies have demonstrated global downregulation of miRNA expression in MPM [16], but the underlying mechanisms driving deregulated miRNA expression in MPM remain largely uncharacterized. MiRNAs are frequently located in genomic regions known to be altered in cancer, including minimal regions of loss of heterozygosity (LOH) and amplification as well as fragile sites and breakpoint regions [29]. Copy number alterations in the $13 \mathrm{q} 14$ chromosomal region, where miR$15 \mathrm{a} / 16-1$ reside, were identified in more than $50 \%$ of B-cell chronic lymphocytic leukemia (B-CLL) tumors resulting in loss of mature miRNA expression [30]. In a genome wide study, approximately $25 \%$ of both ovarian and breast cancer specimens exhibited copy number loss of regions containing mir-15a and mir-16-1 [31]. Similarly, the miR15a/16-1 locus exhibits LOH in NSCLC tumor samples [32] and is frequently deleted in pituitary tumors [33]. Our data are somewhat consistent with these findings; using CNV analysis, we found heterozygous loss of MIR15A/16-1 in H2452 and H2052 but not in the other MPM cell lines tested. In contrast, no deletions were found in the alternative miR-16 cluster, MIR15B/16-2 on chromosome 3q25, in any of the MPM cell line panel. Collectively these data suggest that other mechanisms are also accountable for miR15a/16-1 and miR-15b/16-2 loss in MPM. In comparison, the majority of cell lines were found to have deletion of one allele of the MIR193A locus, therefore attributing loss of mature miR-193a-3p expression to genomic deletion of its coding region in MPM.
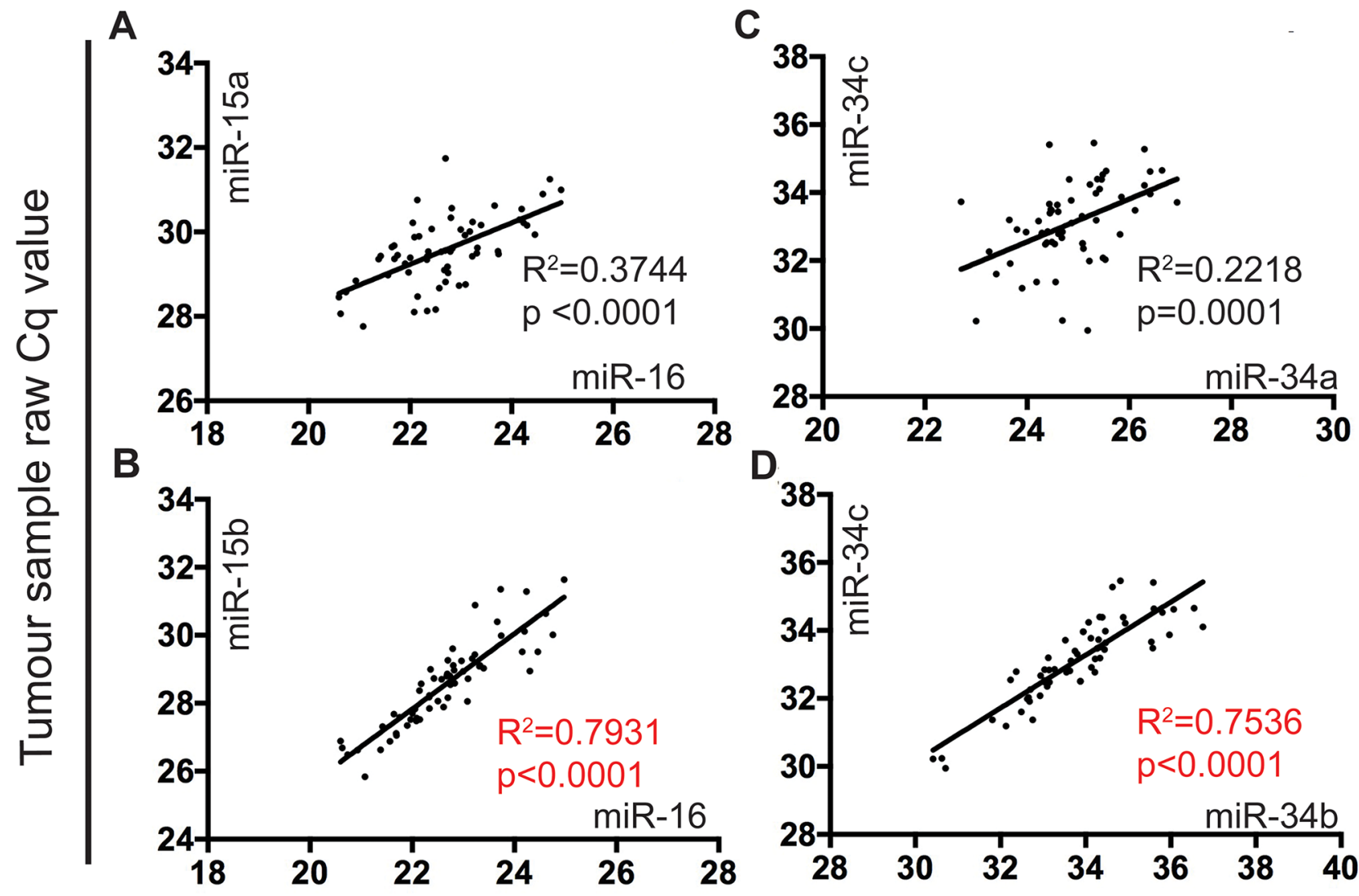

\section{Tumour sample raw Cq value}

Figure 6: The expression of miR-15b and miR-16 is highly correlated in MPM tumor samples. MiRNA expression in FFPE tumor samples $(n=60)$ obtained from patients undergoing EPP were correlated using a linear regression model in Graphpad prism v7. RT-qPCR was used to determine raw Cq values to show correlation of: (A) miR-16 and miR-15a ( $\mathrm{R}^{2}$ correlation coefficient value of 0.3744), (B) miR-16 and miR-15b ( $\mathrm{R}^{2}$ correlation coefficient value of 0.7931$)$, (C) miR-34a and miR-34c ( $\mathrm{R}^{2}$ correlation coefficient value of 0.2218 ), and (D) miR-34b and miR-34c ( $R^{2}$ correlation coefficient value of 0.7536$)$. 
Epigenetic changes frequently modulate miRNA expression in cancer [34]. Family members miR-34b and miR-34c are inactivated due to $\mathrm{CpG}$ methylation in patients with colorectal, pancreatic, mammary, ovarian, urothelial, and renal cell carcinomas and soft tissue sarcomas [35]. In MPM, $85 \%$ of tumors exhibited increased methylation of the miR-34b/c promoter [14], and this methylationinduced loss of miR-34c in MPM was confirmed here by the dramatic increases in miR-34c expression in the MPM cell line panel following treatment with the DNMT inhibitor decitabine. In contrast, the hypermethylation of the MIR193A gene promoter region found in lung cancer [21], AML [36] and ovarian cancer [37] does not appear to contribute to miR-193a-3p downregulation in MPM, as we have suggested previously [23]. Instead, miR-193a-3p loss in MPM cell lines appears to be the result of genomic deletion. Similarly, expression of miR15a/16-1 and miR-15b/16-2 changed little in response to DNMT inhibition. These miRNAs were also unaltered in cell lines treated with the HDAC inhibitor TSA. This contrasts with results reported for MCL and CLL, where miR-15a/16-1 transcription was increased by the addition of histone deacetylase inhibitors [38, 39]. Collectively, this data suggests that epigenetic modifications are not a predominant cause of the substantial reduction of miR$15 \mathrm{a}, 15 \mathrm{~b}$ and 16 expression in MPM cell lines and tumors.

Having excluded epigenetic modifications as predominant mechanisms causing miRNA loss in MPM cell lines, altered transcription factor activity was examined as a mechanism that could repress miRNA transcription, as found in other cancers [34]. Recently, DNA copy number analysis revealed frequent genomic amplification of the $M Y C$ gene in MPM tumor samples and cell lines [27]. c-Myc has integral roles in tumorigenesis by controlling genes involved in cell growth $[24,40]$ and is also implicated in the transcriptional control of miRNA expression [39]. Although Myc is regularly involved in the activation of gene expression, and promotes expression of the oncogenic miR-17-92 cluster in B-cell lymphoma, lung cancer [41] and chronic myeloid leukemia (CML) [42], it has become increasingly clear that Myc directly represses multiple miRNAs in cancer $[26,40,41,43$, 44]. For example, Myc induced widespread repression of multiple miRNAs in B-cell Lymphoma, including the tumor suppressors miR-15a/16-1, miR-34a and let-7, via direct association with their promoter regions [24]. Myc has been implicated in the transcriptional repression of miR-15a/16-1 expression in B-Cell Lymphoma [24, 39], Ewing's sarcoma [26] and colorectal carcinoma [25], and was also shown to interact with HDAC3 to indirectly repress expression of miR-15a/16-1 in Mantle Cell Lymphoma (MCL) [39].

In this study we demonstrated Myc mediated repression of both the miR-15a/16-1 and miR-15b/16-2 clusters. Interestingly, Myc reduction led to dramatic increases in expression from the miR-15b/16-2 region compared with more subtle differences seen for miR15a/16-1. When activating transcription, Myc and its binding partner Max dimerize before binding to gene promoter regions or within the first introns of target gene DNA via canonical DNA binding sites [45]. Alternatively, during transcriptional repression, Myc associates with core promoter regions via protein-protein interactions, where it inhibits positive regulators of transcription [45, 46]. Myc can repress transcription through initiator (Inr) elements in start sites and interaction with promoter-bound transcription factors such as Miz1, Sp1 and Smads [45, 47, 48]. In MPM cell lines, direct association of Myc with the miR-15a/16-1 cluster was demonstrated by enrichment of the DLEU2 promoter regions as described in previous studies [24-26, 39]. Unlike DLEU2, the SMC4 (miR$15 \mathrm{~b} / 16-2)$ promoter region does not contain predicted Myc binding regions and Myc enrichment was instead identified in regions that are known to harbor Inr sites as examined by promoter regulation prediction software (YAPP, MAPPER2). In addition, data from MPM tumor samples indicated a stronger correlation between miR$15 \mathrm{~b}$ and miR-16 than between miR-15a and miR-16. As miR-15b is downregulated to a greater extent than miR15a in MPM tumors [15], and Myc has a greater effect on the miR-15b/16-2 locus, this suggests that the role played by Myc in the reduction of miR-16 in MPM occurs predominantly via suppression of the miR-15b/16-2 locus.

Myc exerts its oncogenic effects by regulating target genes that have roles in multiple processes including apoptosis and cell growth [39], and the dosedependent reduction in MPM cell line proliferation we observe after Myc knockdown suggests that Myc plays a similar role in MPM cell lines. Previously, we and others have shown that restoring expression levels of the miR-15/16 family results in similar cellular consequences to Myc knockdown [15, 49], so it is likely that increased miR-15/16 expression contributes to the effects on proliferation seen following Myc silencing. In addition to inhibition of MPM cell growth, miR-15/16 suppression may also contribute to other Myc-mediated effects. For example, tumor-specific inactivation of Myc expression was shown to reverse immune evasion by preventing the Myc-induced transcriptional activation of PD-L1 and CD47 [50]. Although Myc was shown to bind the promoters of both genes, it is likely that Mycinduced miRNA suppression also plays a role as miR$15 \mathrm{a}, 15 \mathrm{~b}$ and 16 directly regulate PD-L1 expression [51, 52], and furthermore, Myc expression correlates with PD-L1 expression in lung cancer [53]. In this study, patients with tumors positive for both proteins had the poorest prognosis, leading the authors to speculate that Myc expression could serve as a surrogate marker for treatment response. Whether Myc expression influences response to immunotherapy involving checkpoint inhibitors and has value as a biomarker in MPM requires further investigation. 


\section{MATERIALS AND METHODS}

\section{Cell lines and cell culture}

The MPM cell lines MSTO-211H, H28, H2052, $\mathrm{H} 2452$, and the immortalized mesothelial cell line MeT$5 \mathrm{~A}$ were purchased from the American Type Culture Collection (Manassas, VA, USA). The VMC23 cell line was a kind gift from Prof Walter Berger (Institute of Cancer Research, Medical University of Vienna, Austria). All cell lines were cultured in RPMI 1640 supplemented with $10 \%$ fetal bovine serum (both from Thermo Fisher Scientific, Carlsbad, CA, USA) at $5 \% \mathrm{CO}_{2}, 37^{\circ} \mathrm{C}$ and $95 \%$ humidity.

\section{Patient samples}

This study analyzed tumor samples from a previously reported series of MPM patients who underwent extrapleural pneumonectomy (EPP)[15]. This work was approved by the Human Research Ethics Committee (HREC) at Concord Repatriation General Hospital, Sydney (CH62/6/2009/078). Formalin-fixed normal pleural tissue $(\mathrm{n}=23)$ was collected from patients undergoing cardiac or aortic surgery as described [15], as part of a study approved by the HREC at RPAH (X100342). Written informed consent was obtained from all participants.

\section{Genomic DNA extraction and CNV analysis using ddPCR}

Genomic DNA (gDNA) was collected from MPM cell lines using the QIAamp DNA mini kit (Qiagen, Hilden, Germany) according to manufacturer's instructions and quantified using a nanophotometer (Implen, Munich, Germany). CNV of the miRNA coding regions was determined by amplifying $40 \mathrm{ng}$ of gDNA with specific primers (35 nM each, listed in Supplementary Table 1) multiplexed with the RPP30 reference gene and Evagreen chemistry using the Bio-Rad QX200 ${ }^{\mathrm{TM}} \mathrm{ddPCR}^{\mathrm{TM}}$ system (all Bio-Rad Laboratories, Munich, Germany). (See supplementary information for detailed methods).

\section{Decitabine (5'Aza-2'deoxycitidine; 5'Aza-CdR) and Trichostatin A (TSA) treatment}

MPM cell lines were grown to approximately $25 \%$ confluence in $5 \mathrm{~cm}$ cell culture dishes and then treated with decitabine (5'Aza-CdR; final concentration $5 \mu \mathrm{M}$ ) or vehicle (equivalent volume; $0.1 \%$ DMSO) every $24 \mathrm{~h}$ for a total of $120 \mathrm{~h}$ of continuous treatment. Treatment with Trichostatin A (TSA) commenced $24 \mathrm{~h}$ after cells were seeded at a concentration of $1.5 \times 10^{5}$ in $5 \mathrm{~cm}$ cell culture dishes and involved $24 \mathrm{~h}$ of exposure to TSA at a final concentration of $1 \mu \mathrm{M}$ or vehicle (equivalent to 0.05
$\%$ DMSO). On completion of drug treatment, changes in miRNA expression were determined by RT-qPCR as described in section 2.5.

\section{Real-time RT-qPCR}

RNA was extracted from MPM cell lines using TRIzol (Thermo Fisher Scientific) as per manufacturer's instructions, and from laser-capture microdissected FFPE sections as described previously [15]. RNA was quantified using a nanophotometer and stored at $-80^{\circ} \mathrm{C}$ prior to cDNA synthesis. MiRNA was quantified by RT-qPCR as described previously for cell lines and tumor samples [15] using the $2^{-\Delta \Delta C q}$ method [54] (See supplementary information for detailed methods).

\section{siRNA transfection}

C-Myc and control siRNAs were purchased from GenePharma (Shanghai, China; sequences in Supplementary Table 1). Cells were reverse-transfected with siRNAs using Lipofectamine RNAiMAX (Thermo Fisher Scientific) as described previously [55]. Briefly, siRNAs were applied at a final concentration of $20 \mathrm{nM}$ for expression analysis and at 2 -fold serial dilutions starting at $15 \mathrm{nM}$ for determination of cell proliferation. RNA was isolated $24 \mathrm{~h}$ and protein $48 \mathrm{~h}$ after transfection with siRNAs.

\section{Western blot}

Cells were reverse-transfected with siRNAs in 6-well plates as described above and $48 \mathrm{~h}$ later protein was isolated in RIPA buffer and quantified using the Pierce BCA protein assay kit (Thermo Fisher Scientific). Protein expression was measured by SDS-PAGE electrophoresis and Western immunoblotting with a c-Myc antibody (D3N8F; Cell Signaling, Danvers, MA) diluted 1:1000 in blocking buffer overnight at $4^{\circ} \mathrm{C}$. Membranes were stripped before probing with a Beta-actin ( $\beta$-actin) antibody (AC-74, Sigma Aldrich, St. Louis, MO) as a control for protein loading. Chemiluminescence (Clarity Western ECL substrate, Bio-Rad), was used to image bands using the Gel Logic 2200 Imaging system (Kodak, New York, USA). (See supplementary information for detailed methods).

\section{Generation of a c-Myc expression construct}

The coding sequence (CDS) of the c-Myc mRNA (corresponding to the RefSeq entry NM_002467.4) was cloned from total RNA isolated from MSTO cells. The Promega MMLV RT kit was used to reverse transcribe 500 ng total RNA, after which 40 ng of cDNA was amplified using AmpliTaq Gold 360 (Promega) with primers corresponding to the c-Myc CDS (Supplementary Table 1). The resultant PCR amplicon was cloned into the TOPO 
TA vector (Thermo Fisher Scientific) as outlined by the manufacturer and then sub-cloned into the pcDNA3.1 expression vector (Thermo Fisher Scientific) after sequence confirmation by Sanger sequencing (Ramaciotti Centre, UNSW, Sydney).

\section{Transient transfections with expression construct plasmids}

Plasmids (pcDNA3.1(+)MYC or pcDNA3.1(+)) were introduced into $\mathrm{H} 28$ cells by forward transfection with the FuGene transfection reagent (Promega) as per the manufacturer's instructions. RNA was isolated $24 \mathrm{~h}$, and protein $48 \mathrm{~h}$, post transfection. (See supplementary information for detailed methods).

\section{Chromatin immunoprecipitation (ChIP) qPCR}

MSTO and H28 cells were analyzed by ChIP to determine the association of c-Myc with miR-15/16 promoter regions. DNA isolated from untreated cells was subjected to ChIP using the c-Myc antibody with the EZ-ChIP Chromatin Immunoprecipitation Assay kit (Merck-Millipore, Darmstadt, Germany) according to the manufacturer's instructions. qPCR was carried out on the ViiA7 Real Time System with multiple sets of primers specific for the miR-15a/16-1 and miR-15b/16-2 promoter regions as well as a negative control for Myc binding (Supplementary Table 1). Sample enrichment was first evaluated relative to the input (Sample enrichment $=2^{\wedge}[\mathrm{Ct}$ input - Ct IP sample]), after which fold-enrichment was calculated by comparing the enrichment with Myc antibodies to the enrichment for the no-antibody control (Relative enrichment = sample enrichment [Myc IP]/ sample enrichment [no antibody]). (See supplementary information for detailed methods).

\section{Cell proliferation assays}

The effect of Myc knockdown on the proliferation of MPM cell lines was carried out using SYBR Green-based cell proliferation assays as described [15]. Briefly, cells were seeded at a density of $2.5 \times 10^{3}$ per well in a 96 -well plate and reversetransfected with $30 \mathrm{nM}$ or $60 \mathrm{nM}$ Myc and control siRNAs. After freezing plates at $-80^{\circ} \mathrm{C}$, proliferation was measured by adding $150 \mu \mathrm{L}$ of SYBR Greencontaining lysis buffer [55] to wells and incubating at $4^{\circ} \mathrm{C}$ overnight. Plates were equilibrated at room temperature before fluorescence was read on a FLUOstar OPTIMA microplate reader (BMG Labtech, Offenburg, Germany).

\section{Statistical analysis}

Differences in gene expression in cell lines and tumor samples were analyzed with a two-tailed independent samples $t$-test. Mann-Whitney $\mathrm{U}$ test was used to assess differences in cell proliferation. Analyses were performed using SPSS Statistics version 25 (IBM Corp., Armonk, NY) and a $P$-value of $\leq 0.05$ was considered statistically significant. The correlation of tumor miRNA expression was assessed by computing Pearson's correlation coefficient of linear regression data in Graphpad Prism version 7.0b.

\section{CONCLUSIONS}

In summary, our data provide evidence for the contribution of multiple mechanisms in the downregulation of tumor suppressor miRNAs in MPM. A combination of genomic deletion and transcriptional repression - rather than hypermethylation - contribute to miR-193a, miR15a/16-1 and miR-15b/16-2 downregulation. Additionally, the mechanisms responsible for suppression of specific miRNAs appear to differ in MPM compared with other malignancies. Interestingly, in MPM, Myc seems to regulate miR-15/16 expression primarily via control of the miR-15b/16-2 locus. This data suggests that regulation of miR-15/16 may be an important contributor to the oncogenic activity of Myc in MPM [25, 26, 39].

\section{Abbreviations}

MPM, malignant pleural mesothelioma; CNV, copy number variation; ddPCR, droplet digital PCR; TSA, trichostatin A; ChIP, chromatin immunoprecipitati on; ncRNAs, noncoding RNAs; miRNAs, microRNAs; 3'UTR, 3' untranslated region; mRNAs, messenger RNAs; pri-miRNAs, primary microRNA transcripts; AML, acute myeloid leukemia; EPP, extrapleural pneumonectomy; HREC, Human Research Ethics Committee; gDNA, genomic DNA; 5'Aza-CdR, 5'Aza2 'deoxycitidine; $\beta$-actin, beta-actin; $\mathrm{CDS}$, coding sequence; LOH, loss of heterozygosity; B-CLL, B-cell chronic lymphocytic leukemia; CML, chronic myeloid leukemia; MCL, mantle cell lymphoma; Inr, initiator.

\section{Author contributions}

MW and GR conceived the project idea and planned the experiments. MW conducted all of the experiments with assistance from YYC, KHS and KS. MBK carried out the RT-qPCR analysis of tumor samples. MW analyzed the data with assistance from YYC, MBK, KS and PW. $\mathrm{BM}$ collected the tumor samples. SK and NVZ provided clinical advice, MW wrote the manuscript, which was further edited by all co-authors.

\section{ACKNOWLEDGMENTS}

The authors would like to acknowledge Michael Vallely and James Edelman for their collection of normal 
mesothelium tissue used in this study and ADRI director Professor Ken Takahashi for his valuable input during the editing process of the article.

\section{CONFLICTS OF INTEREST}

The authors declare that they have no conflicts of interests.

\section{FUNDING}

This work was supported by a Program Grant from the Cancer Institute New South Wales (NvZ \& GR), the Swift Family Bequest (MBK) and a Sydney Catalyst PhD fellowship (MW).

\section{REFERENCES}

1. Tsao AS, Wistuba I, Roth JA, Kindler HL. Malignant pleural mesothelioma. J Clin Oncol. 2009; 27:2081-90. https://doi.org/10.1200/jco.2008.19.8523. [PubMed]

2. Li Y, VandenBoom TG, 2nd, Kong D, Wang Z, Ali S, Philip PA, Sarkar FH. Up-regulation of miR-200 and let-7 by natural agents leads to the reversal of epithelialto-mesenchymal transition in gemcitabine-resistant pancreatic cancer cells. Cancer Res. 2009; 69:6704-12. https://doi.org/10.1158/0008-5472.can-09-1298. [PubMed]

3. Kelly RJ, Sharon E, Hassan R. Chemotherapy and targeted therapies for unresectable malignant mesothelioma. Lung Cancer. 2011; 73:256-63. https://doi.org/10.1016/j.lungcan.2011.04.014. [PubMed]

4. Roe OD, Anderssen E, Sandeck H, Christensen $\mathrm{T}$, Larsson E, Lundgren S. Malignant pleural mesothelioma: genome-wide expression patterns reflecting general resistance mechanisms and a proposal of novel targets. Lung Cancer. 2010; 67:57-68 https://doi.org/10.1016/j.lungcan.2009.03.016. [PubMed].

5. Romagnoli S, Fasoli E, Vaira V, Falleni M, Pellegrini C, Catania A, Roncalli M, Marchetti A, Santambrogio L, Coggi G, Bosari S. Identification of potential therapeutic targets in malignant mesothelioma using cell-cycle gene expression analysis. Am J Pathol. 2009; 174:762-70. https://doi.org/10.2353/ajpath.2009.080721. [PubMed]

6. Ceresoli GL, Mantovani A. Immune checkpoint inhibitors in malignant pleural mesothelioma. Lancet Oncol. 2017; 18:559-61. https://doi.org/10.1016/S1470-2045(17)30191-2. [PubMed]

7. Zou W, Wolchok JD, Chen L. PD-L1 (B7H1) and PD-1 pathway blockade for cancer therapy: Mechanisms, response biomarkers, and combinations. Sci Transl Med. 2016; 8:328rv4. https://doi.org/10.1126/scitranslmed.aad7118. [PubMed]

8. Calabrò L, Morra A, Cornelissen R, Aerts J, Maio M. Immune checkpoint blockade therapy of mesothelioma: a clinical and radiological challenge.
Cancer Immunol Immunother. 2018; 67:1317-24. https://doi.org/10.1007/s00262-018-2191-3. [PubMed]

9. Ha M, Kim VN. Regulation of microRNA biogenesis. Nat Rev Mol Cell Biol. 2014; 15:509-24. https://doi.org/10.1038/nrm3838. [PubMed]

10. Jansson MD, Lund AH. MicroRNA and cancer. Mol Oncol. 2012; 6:590-610. http://dx.doi.org/10.1016/j.molonc.2012.09.006. [PubMed]

11. Macias S, Michlewski G, Cáceres JF. Hormonal Regulation of MicroRNA Biogenesis. Mol Cell. 2009; 36:172-73. http://dx.doi.org/10.1016/j.molcel.2009.10.006. [PubMed]

12. Calin GA, Croce CM. MicroRNA signatures in human cancers. Nat Rev Cancer. 2006; 6:857-66. https://doi.org/10.1038/nrc1997. [PubMed]

13. Lu J, Getz G, Miska EA, Alvarez-Saavedra E, Lamb J, Peck D, Sweet-Cordero A, Ebert BL, Mak RH, Ferrando AA, Downing JR, Jacks T, Horvitz HR, Golub TR. MicroRNA expression profiles classify human cancers. Nature. 2005; 435:834-8. https://doi.org/10.1038/nature03702. [PubMed]

14. Kubo T, Toyooka S, Tsukuda K, Sakaguchi M, Fukazawa T, Soh J, Asano H, Ueno T, Muraoka T, Yamamoto H, Nasu Y, Kishimoto T, Pass HI, et al. Epigenetic silencing of microRNA$34 \mathrm{~b} / \mathrm{c}$ plays an important role in the pathogenesis of malignant pleural mesothelioma. Clin Cancer Res. 2011; 17:4965-74. https://doi.org/10.1158/1078-0432.CCR-10-3040. [PubMed]

15. Reid G, Pel ME, Kirschner MB, Cheng YY, Mugridge N, Weiss J, Williams M, Wright C, Edelman JJ, Vallely MP, McCaughan BC, Klebe S, Brahmbhatt $\mathrm{H}$, et al. Restoring expression of miR-16: a novel approach to therapy for malignant pleural mesothelioma. Ann Oncol. 2013; 24:312835. https://doi.org/10.1093/annonc/mdt412. [PubMed]

16. Reid G. MicroRNAs in mesothelioma: from tumour suppressors and biomarkers to therapeutic targets. J Thorac Dis. 2015; 7:1031-40. https://doi.org/10.3978/j.issn.2072-1439.2015.04.56. [PubMed]

17. Williams M, Cheng YY, Blenkiron C, Reid G. Exploring Mechanisms of Microrna Downregulation in Cancer. Microrna. 2017; 6:2-16. https://doi.org/10.2174/2211536605666161208154633. [PubMed]

18. Muraoka T, Soh J, Toyooka S, Aoe K, Fujimoto N, Hashida S, Maki Y, Tanaka N, Shien K, Furukawa M, Yamamoto H, Asano H, Tsukuda K, et al. The degree of microRNA$34 \mathrm{~b} / \mathrm{c}$ methylation in serum-circulating DNA is associated with malignant pleural mesothelioma. Lung Cancer. 2013; 82:485-90. https://doi.org/10.1016/j.lungcan.2013.09.017. [PubMed]

19. Ivanov SV, Goparaju CM, Lopez P, Zavadil J, TorenHaritan G, Rosenwald S, Hoshen M, Chajut A, Cohen D, Pass HI. Pro-tumorigenic effects of miR-31 loss in mesothelioma. J Biol Chem. 2010; 285:22809-17. https://doi.org/10.1074/jbc.M110.100354. [PubMed]

20. Reid G, Kao SC, Pavlakis N, Brahmbhatt H, MacDiarmid J, Clarke S, Boyer M, van Zandwijk N. Clinical development 
of TargomiRs, a miRNA mimic-based treatment for patients with recurrent thoracic cancer. Epigenomics. 2016; 8:107985. https://doi.org/10.2217/epi-2016-0035. [PubMed]

21. Heller G, Weinzierl M, Noll C, Babinsky V, Ziegler B, Altenberger C, Minichsdorfer C, Lang G, Dome B, EndPfutzenreuter A, Arns BM, Grin Y, Klepetko W, et al. Genome-wide miRNA expression profiling identifies miR9-3 and miR-193a as targets for DNA methylation in nonsmall cell lung cancers. Clin Cancer Res. 2012; 18:1619-29. https://doi.org/10.1158/1078-0432.ccr-11-2450. [PubMed]

22. Gao XN, Lin J, Li YH, Gao L, Wang XR, Wang W, Kang HY, Yan GT, Wang LL, Yu L. MicroRNA-193a represses c-kit expression and functions as a methylation-silenced tumor suppressor in acute myeloid leukemia. Oncogene. 2011; 30:3416. https://doi.org/10.1038/onc.2011.62. [PubMed]

23. Williams M, Kirschner MB, Cheng YY, Hanh J, Weiss J, Mugridge N, Wright CM, Linton A, Kao SC, Edelman JJ, Vallely MP, McCaughan BC, Cooper W, et al. miR$193 a-3 p$ is a potential tumor suppressor in malignant pleural mesothelioma. Oncotarget. 2015; 6:23480-23495. https://doi.org/10.18632/oncotarget.4346. [PubMed]

24. Chang TC, Yu D, Lee YS, Wentzel EA, Arking DE, West KM, Dang CV, Thomas-Tikhonenko A, Mendell JT. Widespread microRNA repression by Myc contributes to tumorigenesis. Nat Genet. 2008; 40:43-50. https://doi.org/10.1038/ng.2007.30. [PubMed]

25. Xue G, Yan HL, Zhang Y, Hao LQ, Zhu XT, Mei Q, Sun $\mathrm{SH}$. c-Myc-mediated repression of miR-15-16 in hypoxia is induced by increased HIF- $2 \alpha$ and promotes tumor angiogenesis and metastasis by upregulating FGF2. Oncogene. 2014; 34:1393. https://doi.org/10.1038/onc.2014.82. [PubMed]

26. Kawano $M$, Tanaka $K$, Itonaga I, Iwasaki $T$, Tsumura H. c-Myc Represses Tumor-Suppressive microRNAs, let-7a, miR-16 and miR-29b, and Induces Cyclin D2-Mediated Cell Proliferation in Ewing's Sarcoma Cell Line. PLoS One. 2015; 10:e0138560. https://doi.org/10.1371/journal.pone.0138560. [PubMed]

27. Riquelme E, Suraokar MB, Rodriguez J, Mino B, Lin HY, Rice DC, Tsao A, Wistuba II. Frequent coamplification and cooperation between C-MYC and PVT1 oncogenes promote malignant pleural mesothelioma. J Thorac Oncol. 2014; 9:998-1007. https://doi.org/10.1097/JTO.0000000000000202. [PubMed]

28. Mao DY, Watson JD, Yan PS, Barsyte-Lovejoy D, Khosravi F, Wong WW, Farnham PJ, Huang TH, Penn LZ. Analysis of Myc bound loci identified by $\mathrm{CpG}$ is land arrays shows that Max is essential for Mycdependent repression. Curr Biol. 2003; 13:882-6. https://doi.org/10.1016/S0960-9822(03)00297-5.

[PubMed]

29. Calin GA, Sevignani C, Dumitru CD, Hyslop T, Noch E, Yendamuri S, Shimizu M, Rattan S, Bullrich F, Negrini M, Croce CM. Human microRNA genes are frequently located at fragile sites and genomic regions involved in cancers. Proc Natl Acad Sci U S A. 2004; 101:2999-3004. https://doi.org/10.1073/pnas.0307323101. [PubMed]

30. Calin GA, Dumitru CD, Shimizu M, Bichi R, Zupo S, Noch E, Aldler H, Rattan S, Keating M, Rai K, Rassenti L, Kipps T, Negrini M, et al. Frequent deletions and down-regulation of micro- RNA genes miR15 and miR16 at 13q14 in chronic lymphocytic leukemia. Proc Natl Acad Sci U S A. 2002; 99:15524-9. $\quad$ https://doi.org/10.1073/pnas.242606799. [PubMed]

31. Zhang L, Huang J, Yang N, Greshock J, Megraw MS, Giannakakis A, Liang S, Naylor TL, Barchetti A, Ward MR, Yao G, Medina A, O'brien-Jenkins A, Katsaros D, et al. microRNAs exhibit high frequency genomic alterations in human cancer. Proc Natl Acad Sci U S A. 2006; 103:9136-41. https://doi.org/10.1073/pnas.0508889103. [PubMed]

32. Bandi N, Zbinden S, Gugger M, Arnold M, Kocher V, Hasan L, Kappeler A, Brunner T, Vassella E. miR-15a and miR-16 are implicated in cell cycle regulation in a Rb-dependent manner and are frequently deleted or down-regulated in non-small cell lung cancer. Cancer Res. 2009; 69:5553-9. https://doi.org/10.1158/0008-5472.Can-08-4277. [PubMed]

33. Bottoni A, Piccin D, Tagliati F, Luchin A, Zatelli MC, degli Uberti EC. miR-15a and miR-16-1 down-regulation in pituitary adenomas. J Cell Physiol. 2005; 204:280-85. https://doi.org/10.1002/jep.20282. [PubMed]

34. Iorio $\mathrm{MV}$, Croce $\mathrm{CM}$. MicroRNA dysregulation in cancer: diagnostics, monitoring and therapeutics. A comprehensive review. EMBO Mol Med. 2012; 4:143-59. https://doi.org/10.1002/emmm.201100209. [PubMed]

35. Vogt M, Munding J, Gruner M, Liffers ST, Verdoodt B, Hauk J, Steinstraesser L, Tannapfel A, Hermeking $\mathrm{H}$. Frequent concomitant inactivation of miR-34a and $\mathrm{miR}-34 \mathrm{~b} / \mathrm{c}$ by $\mathrm{CpG}$ methylation in colorectal, pancreatic, mammary, ovarian, urothelial, and renal cell carcinomas and soft tissue sarcomas. Virchows Arch. 2011; 458:31322. https://doi.org/10.1007/s00428-010-1030-5. [PubMed]

36. Li Y, Gao L, Luo X, Wang L, Gao X, Wang W, Sun J, Dou L, Li J, Xu C, Wang L, Zhou M, Jiang $\mathrm{M}$, et al. Epigenetic silencing of microRNA193a contributes to leukemogenesis in $t(8 ; 21)$ acute myeloid leukemia by activating the PTEN/ PI3K signal pathway. Blood. 2013; 121:499-509. https://doi.org/10.1182/blood-2012-07-444729. [PubMed]

37. Chen K, Liu MX, Mak CS, Yung MM, Leung TH, Xu D, Ngu SF, Chan KK, Yang H, Ngan HY, Chan DW. Methylation-associated silencing of miR-193a-3p promotes ovarian cancer aggressiveness by targeting GRB7 and MAPK/ERK pathways. Theranostics. 2018; 8:423-36. https://doi.org/10.7150/thno.22377. [PubMed]

38. Sampath D, Liu C, Vasan K, Sulda M, Puduvalli VK, Wierda WG, Keating MJ. Histone deacetylases mediate the silencing of miR-15a, miR-16, and miR-29b in chronic lymphocytic leukemia. Blood. 2012; 119:1162-72. https://doi.org/10.1182/blood-2011-05-351510. [PubMed] 
39. Zhang $X$, Chen $X$, Lin J, Lwin T, Wright G, Moscinski LC, Dalton WS, Seto E, Wright K, Sotomayor E, Tao J. Myc represses miR-15a/miR-16-1 expression through recruitment of HDAC3 in mantle cell and other nonHodgkin B-cell lymphomas. Oncogene. 2012; 31:3002-08. https://doi.org/10.1038/onc.2011.470. [PubMed]

40. Davis BN, Hata A. Regulation of MicroRNA Biogenesis: A miRiad of mechanisms. Cell Commun Signal. 2009; 7:18. https://doi.org/10.1186/1478-811X-7-18. [PubMed]

41. Hayashita Y, Osada H, Tatematsu Y, Yamada H, Yanagisawa K, Tomida S, Yatabe Y, Kawahara K, Sekido Y, Takahashi T. A polycistronic microRNA cluster, miR-17-92, is overexpressed in human lung cancers and enhances cell proliferation. Cancer Res. 2005; 65:9628-32. https://doi.org/10.1158/0008-5472.can-05-2352. [PubMed]

42. Venturini L, Battmer K, Castoldi M, Schultheis B, Hochhaus A, Muckenthaler MU, Ganser A, Eder M, Scherr M. Expression of the miR-17-92 polycistron in chronic myeloid leukemia (CML) CD34+ cells. Blood. 2007; 109:4399-405. https://doi.org/10.1182/blood-2006-09-045104. [PubMed]

43. Gao P, Tchernyshyov I, Chang TC, Lee YS, Kita K, Ochi T, Zeller KI, De Marzo AM, Van Eyk JE, Mendell JT, Dang CV. c-Myc suppression of miR$23 \mathrm{a} / \mathrm{b}$ enhances mitochondrial glutaminase expression and glutamine metabolism. Nature. 2009; 458:762-5. https://doi.org/10.1038/nature07823. [PubMed]

44. Zhang X, Zhao X, Fiskus W, Lin J, Lwin T, Rao R, Zhang Y, Chan John C, Fu K, Marquez Victor E, Chen-Kiang S, Moscinski Lynn C, Seto E, et al. Coordinated Silencing of MYC-Mediated miR-29 by HDAC3 and EZH2 as a Therapeutic Target of Histone Modification in Aggressive B-Cell Lymphomas. Cancer Cell. 2012; 22:506-23. https://doi.org/10.1016/j.ccr.2012.09.003. [PubMed]

45. Luo Q, Li J, Cenkci B, Kretzner L. Autorepression of c-myc requires both initiator and E2F-binding site elements and cooperation with the p107 gene product. Oncogene. 2004; 23:1088-97. https://doi.org/10.1038/sj.onc.1207225. [PubMed]

46. Kleine-Kohlbrecher D, Adhikary S, Eilers M. Mechanisms of transcriptional repression by Myc. Curr Top Microbiol Immunol. 2006; 302:51-62. [PubMed]

47. Si J, Yu X, Zhang Y, DeWille JW. Myc interacts with Max and Mizl to repress $\mathrm{C} / \mathrm{EBP} \delta$ promoter activity and gene expression. Molecular Cancer. 2010; 9:92. https://doi.org/10.1186/1476-4598-9-92. [PubMed]

48. Wiese KE, Walz S, von Eyss B, Wolf E, Athineos D, Sansom O, Eilers M. The Role of MIZ-1 in MYC-Dependent Tumorigenesis. Cold Spring Harb Perspect Med. 2013; 3:a014290. https://doi.org/10.1101/cshperspect.a014290. [PubMed]

49. Aqeilan RI, Calin GA, Croce CM. miR-15a and miR-16-1 in cancer: discovery, function and future perspectives. Cell Death Differ. 2010; 17:215-20. https://doi.org/10.1038/cdd.2009.69. [PubMed]

50. Casey SC, Tong L, Li Y, Do R, Walz S, Fitzgerald KN, Gouw AM, Baylot V, Gutgemann I, Eilers M, Felsher DW. MYC regulates the antitumor immune response through CD47 and PD-L1. Science. 2016; 352:227-31. https://doi.org/10.1126/science.aac9935. [PubMed]

51. Kao SC, Cheng YY, Williams M, Kirschner MB, Madore J, Lum T, Sarun KH, Linton A, McCaughan B, Klebe S, van Zandwijk N, Scolyer RA, Boyer MJ, et al. Tumor Suppressor microRNAs Contribute to the Regulation of PD-L1 Expression in Malignant Pleural Mesothelioma. J Thorac Oncol. 2017; 12:1421-33. https://doi.org/10.1016/j.jtho.2017.05.024. [PubMed]

52. Jia X, Li X, Shen Y, Miao J, Liu H, Li G, Wang Z. MiR16 regulates mouse peritoneal macrophage polarization and affects T-cell activation. J Cell Mol Med. 2016; 20:1898907. https://doi.org/10.1111/jcmm.12882. [PubMed]

53. Kim EY, Kim A, Kim SK, Chang YS. MYC expression correlates with PD-L1 expression in non-small cell lung cancer. Lung Cancer. 2017; 110:63-7. https://doi.org/10.1016/j.lungcan.2017.06.006. [PubMed]

54. Livak KJ, Schmittgen TD. Analysis of relative gene expression data using real-time quantitative PCR and the 2(-Delta Delta C(T)) Method. Methods. 2001; 25:402-8. https://doi.org/10.1006/meth.2001.1262. [PubMed]

55. Reid G, Wallant NC, Patel R, Antonic A, Saxon-Aliifaalogo F, Cao H, Webster G, Watson JD. Potent subunit-specific effects on cell growth and drug sensitivity from optimised siRNAmediated silencing of ribonucleotide reductase. Journal of RNAi and Gene Silencing : An International Journal of RNA and Gene Targeting Research. 2009; 5:321-30. [PubMed] 